\title{
Topic: Tiv Traditional Conception of the Human Person Okwa Felix Agbo*
}

Augustinian Institute of Philosophy, Makurdi, Benue State, Nigeria

"Corresponding author: Felix Agbo O, Augustinian Institute of Philosophy, Makurdi, Benue State, Nigeria, Tel: (610)519-4500; E-mail: okwafa@yahoo.com

Received date: October 26, 2016; Accepted date: December 15, 2016; Published date: December 21, 2016

Copyright: (c) 2016 Felix Agbo O. This is an open-access article distributed under the terms of the Creative Commons Attribution License, which permits unrestricted use, distribution, and reproduction in any medium, provided the original author and source are credited.

\begin{abstract}
Among the Tiv people, the human person is constituted by four basic components: The Or which refers to the human person, man or woman. The lyol, which is the body and material part of the human person. The Uma, which is life and the Jijingi which is the spirit that is demonstrated by the shadow the body radiates. The other important aspect of the Human person for the Tiv is the Ishima (heart). In this work, we bring out the intricacies involved and evident in the divisions of the human person by the Tiv culture which in turn brings about the beauty of the African culture and the eschatology of the Tiv Culture. The question however is, does all these divisions of the human person appeal to logic and reason? How do all these work together harmoniously to form a perfect being? Are there moments of conflicts between the aspects of the person? All these are the many aspects been interrogated by this work.
\end{abstract}

Keywords: Human Person; Ishima; Jijingi; Ubo; Mbatsav

\section{Introduction}

Most cultures of the world entertain ideas and teachings concerning the Conception of the Human Person. The Tiv or Tivi cultural people of Nigeria are obviously not an exception to these world cultures in which the conception of the human person is been articulated and expressed. This work titled "Tiv Traditional Conception of the Human Person" is a work aimed at studying critically the Conception of the Human Person in the Tiv Cultural milieu.

On the whole, we shall underscore the importance of the conception of the human person as well as how it affects the ideas, belief system and practices of every aspect of Tiv culture. To do this effectively, we shall engage in a systematic fashion starting with an expose of the history and origin of the Tiv people of Benue State.

The concept Human Person is obviously not alien to any traditional culture in Africa, however, it might be said to differ in the various cultures for in constructing our individual or communal world views, we first and foremost come to terms with our experiences from our immediate environment and this is said to be common with every culture. For example, while the Yoruba people understand the human person as eniyan, comprising of ara, okan, emi and ori, the Igbo people understand the human person as Mmadu, comprising of obi, onyinyo, eke and chi. We shall thus delve into the crust of the work: The Tiv Traditional Conception of the Human Person.

In the Tiv culture, the word "Ishima" which means Good Heart is very important. We shall hence make a comparison between this Tiv concept and Mutumin Kirki in the Hausa culture. Finally, we shall briefly but critically discuss the eschatological conception of the Tiv people. The question however is, what are the Tiv teachings or understanding about the 'last things'? This shall consequently lead us to the conclusion.

\section{History and Origin of the Tiv People}

There seems to be numerous submissions about the origin of the Tiv. However, according to Torkula, a view which is most celebrated, the Tiv people are said to trace their origin to the Bantu people, the onetime inhabitants of Central Africa, present day Democratic Republic of Congo [1]. The Tiv people are thus regarded as a unique ethnic group of semi-Bantu linguistic affinity. They are currently the majority group or inhabitants of Benue State. They speak one common language and are said to possess a unique sort of religious and social practice. They are said to constitute approximately $2.5 \%$ of Nigeria's total population, which invariably implies that there are about 6 million Tiv speakers.

The Tiv people are traditionally mostly agrarian farmers; they regard farming as their birthright and thus commit themselves with religious and total dedication. Few of them however, engage in traditional weaving, an enterprise among the Tiv that is passed from one generation to the other, hence, many who are engage in such are said to have inherited it as family business. Since many occasions demand traditional attires, this activity is said to be increasing its market spheres [1]. The most notable among the fabrics are the Anger (the black and white), the Tugudu which is used for burying the dead and the Ivvavtyo, which is exclusively used by women.

The traditional Tiv society was completely egalitarian; there was no central ruler or authority. They had no king, so every man was ruler of his house. They lived in compounds administered by the oldest man. It was until the colonialists came and established a Tiv central authority and the paramount ruler called the Tor Tiv lived and still lives and administers the Tiv people from Gboko. Till date, Gboko is regarded as the headquarters of the Tiv people. The Tiv people are known for their storytelling, their unique dance craft, poetic creativity and general aesthetic profundity [1].

\section{Tiv Traditional Conception of the Human Person}

From our exposition about the various conceptions of the human person, we would easily understand that the perception of the human 
Page 2 of 3

person varies from culture to culture as well as from one discipline to another. According to Fromm, the human person could be viewed biologically, anatomically, physiologically and psychologically [2]. The focus of the traditional African conception or interpretation of the human person however is very different. For example, as stated in the introduction, the Igbo conception of the human person emphasizes four constituent principles. While the man is known as Mmadu, Metuh argues that other important constituent principles include: Ahu-body Obi-Heart or breath, Onyinyo-Shadow spirit, Chi-Destiny spirit (personal god) [3]. From the foregoing, one could easily deduce that this African Traditional conception of the human person might not judiciously fit into the biological, anatomical, physiological, or psychological conception of the human person especially as put forward by Fromm.

Among the Tiv people, the human person is constituted by four basic components. First and foremost, a human person in Tiv is referred to as $O r$. The $O r$ therefore is used to refer to a man or a woman. The $O r$ which is similar to the eniyan in Yoruba and the mmadu in Igbo, has an important part, the Iyol, which is the body. The Iyol is therefore the material and of course the physical part of the human person. The Oralso has the Uma, which is life. Aside this Uma, the Tiv people believe there is a life force which keeps the Or alive, this for them is a spirit that is demonstrated by the shadow the body radiates, this they refer to as the Jijingi. Aside all these, another very important aspect of $O r$ is Ishima which is the heart. The heart according to them is where the psychic-power as well as the vital force and energy of the human person dwell. It is therefore the Ishima that ignites and dynamites the stored spiritual energy in any person. Hence, the idea of Tsav which means witch is highly unnatural and hence not common to a typical Tiv man. According to Tarbo, and owing from the above, the body which is the Or is perishable, consequently, the Uma (life) which could be likened to the Soul and the life force, the Jijingi which together form the imperishable part of man have endless sort of existence. The indestructible part of man, the spirit according to the Tiv people, has a divine origin and therefore sacred, hence they frown at man unkind to mankind [4]. The Tiv people believe in one God, he is referred to as Aondo. There are no divinities in Tiv land.

All these components of the human person are said to have specific roles, which together forms the unity. This $O r$ is at the center of the universe possessing multi-dimensional relationship both in the physical and spiritual realities, consequently, man in his complex psycho-physical essence ought to strive to maintain unity of the created order, Igbetar [5]. The Iyol for the Tiv man must necessarily be kept alive, healthy and active, with vitality for vigorous activities like farming, giving birth and interactions with other members of the community. Hence, the Iyol is said to respond to the external demands of the Tar (land). To be able to maintain unity of the created order, Ishima Idedoo (a Good Heart) is required and not Ishima Ibo (Bad Heart). Furthermore, the Tiv conception of the world is psychospiritual. Psycho-spiritual in the sense that everything visible has its equivalent in the invisible sphere [6]. An idea slightly different from the idea of world of forms and world of particular by Plato.

In addition, the Tiv people believe man has a purpose on earth. Put differently, the Tiv person believe man has a mission to perform here on earth, this mission is to live life to its fullness, to marry, to have children, to belong to any profession assigned to him/her by the Aondo, to interact with the community, both of the living and the dead and finally to join the ancestors after death. This conception of the mission of man on earth serves as the backdrop to the reasons for the activities and ways of life of the typical Tiv man. For example, the mission to live life to its fullness could be said to account for the way the Tiv people celebrates life. They are said to be socially liberal, eating lots of pork (Nyamgyo), lots of alcoholic beverages and so on. This conception could also be said to be the reason for the promiscuity recorded among the Tiv people, both single and married: to live life to its fullness. We can therefore state that, the Tiv oral tradition represents the underlying truth behind the life of the Tiv people their mission on earth, religious outlook and elements of eschatology.

\section{'Ishima Idedoo' and the Hausa Concept of 'Mutumin Kirki'}

Owing from our exposition of the Tiv concept of the human person, we stated clearly that the Tiv people believe that Tsav, which means witch, propelled by Ishima ibo (bad heart), is unnatural and so uncommon. Hence, they believe that every man is supposed to be good. The Ishima idedoo as stated earlier, is what is required of a typical Tiv person-a good heart, this Ishima idedoo consequently is said to aid the human person to maintain that unity of the created order (Igbetar). This Ishima idedoo is said to be that propelling force in a typical Tiv man to keep the rules of his community and culture in order to maintain the smooth running of the community. Hence, what Ishima ibo does is to create disorder, compelling people to become Tsav and continuously cause evil or badness in the community, this thus breeds disequilibrium in the community [1].

There is a similar conception of Ishima idedoo in the Hausa culture: Mutumin Kirki, a good man. Mutumin Kirki in the Hausa culture represents the ideal of personal goodness. Obvious in the Hausa society is that ideal expectation that its members attain an ideal of being a Mutumin Kirki [7]. This view according to Kirk-Greene hence brings to the fore or partly underscores one fundamental thing that the Hausa thought pattern and worldview about the world, humanity and life revolves around moral virtue. Little wonder we notice the use of Gaskiya which means "truth" occurring most frequently during Hausa conversation than most observed cultures of the world [7]. A Mutumin Kirki is therefore expected to be truthful in all his dealings (Hali). If you go to the market to buy something in a Hausa man's shop for example, and he tells you "Gaskiya its 500 naira", it invariably means that the truth value of that said commodity is 500 naira, no more no less. However, we should note that, with the advent of globalization and the growth of low culture, as well as loss of morals, a typical Hausa man can actually tell you "Gaskiyan kenan", in fact, even mention Allah, and actually be lying about the price of the commodity [8]. Furthermore, a Mutumin kirki is also expected to be very generous (Karamci), patient (Hakuri), prudent and well behaved (Hankali), to possess a sort of proper sense of shame (Kunya) and finally wisdom and honesty in one's dealings [7].

It is therefore obvious that, should all in the society endeavor to become Mutumin kirki or possess Ishima idedoo, the world could actually become a better place and we shall be able to maintain that unity of the created order (Igbetar) as well as be able to give every human person his or her due in the community.

\section{Eschatology in Tiv Traditional Culture}

The first question to ask at this point is, what is eschatology? Etymologically, eschatology is derived from two Greek words, "eschatos" and "eschata" which mean last and last things respectively [8]. Owing from this Greek origin, eschatology could be said to 
Page 3 of 3

literally mean the teachings or better still, the science concerning the last things. According to Joseph Omoregbe, in the Christian theology, the last things could mean death, judgment, heaven and hell [9].

In the African purview however, it is important to mention that, eschatology is a fairly recent realm of scholarship, which could be traced back to Mbiti. Since our purpose here is the eschatology in Tiv traditional culture, we therefore move quickly to engage in our discussion in order to unravel its conception and articulate the aspects of the Tiv cultural life that supports this notion. As observed, eschatology is neither English nor a Tiv word. So, there is no single word in Tiv language that can adequately express the entire ideas embedded in the term eschatology. The Tiv word for death is $\mathrm{Ku}$, and this is indeed a dreadful term and seems very mysterious as the Tiv people don't believe there is any death that is uncaused.

The Tiv people are said to possess a sort of power capable of reviving the dead. The Tiv word for this is "Kpen" revival of the dead. Aside those who are thought to have been unjustly killed; a wicked person could be revived for the purpose of torturing him or her. Furthermore, the Tiv strongly believe in judgment. Little wonder they strongly advocate the Ishima idedoo. Even though their concept of judgment is slightly different from the English conception, for the typical Tiv man, judgment is done by day as well as by night. During the judgment by day, the elders usually seek to know the cause(s) of the death of a person and hence prevent its occurrences in the family. During the judgment by night, there exists serious revival and communion with the ancestors. This therefore accounts for why the Tiv people are perceived to celebrate the death of their member, because after the judgment by day, the revival and communion with the ancestors by night is usually full of merriment, dining and dancing, eating and chatting. Kunun Tamen is the name for the land of the dead or hell in the English language where those who died with Ishima ibo finally end, or Takuruku where the great ancestors reside, which could be likened to heaven, where those with Ishima Idedoo go to. The burial of Tiv elders are mostly in the evenings, for peaceful rest in the ancestral world. For them, the dark is time for spiritual communion of the living and the dead. The nature of a man's burial determines his peaceful rest and afterlife. Hence, a typical Tiv man is more concerned with the nature of his burial than the present life.

There are two forms of death in the Tiv culture: Ku dedoo and $\mathrm{Ku}$ ubo, which means good death and bad death respectively. The Ku dedoo goes with all funeral rites unlike the Ku ubo. A typical Tiv burial rite begins with a message to the great ancestor (Takuruku), intimating him of the death and requesting his presence to come and wait and receive the person into the ancestral world. On the day of the burial, elderly women wash the deceased in order to enable him/her to enter the spirit world neatly and well dressed in the traditional attire. A typical Tiv burial is normally within twenty four hours. This could be said to be similar to the burial rites of the Muslims.

In some areas, burial is performed with household utensils, clothing, and formally one's servant; these are for use in the spirit world. This burial rite is similar to the burial rite of a traditional Igbo culture, especially as recorded by Buchi Emecheta in "The Joys of Motherhood". However, Ku ubo, death through drowning, suicide or having swollen stomach at death is not accorded this burial rite. For the judgment, the first night after the burial, the elders, referred to as the Mbatsav, usually summons the dead person to be judged. A very good person, who has lived a moral life following the Ishima idedoo, becomes an ancestor, while a wicked man could be tortured and cut into pieces. This punishment for the wicked man may extend to members of his family who are still living. However, not in the same manner, hence, they might be punished in terms of pre-mature death, poor harvest, and lack of prosperity and so on.

\section{Evaluation and Conclusion}

Having completed a vivid analysis of the Tiv Traditional Conception of the Human Person, we might conclude herein that, the Tiv traditional conception of the human person is vital and pivotal to all the aspects of Tiv culture and indeed of Tiv heritage. Their conception of the human person consequently affects all the aspects of their life: their marriage, social interactions, artworks, dance, songs, as well as their understanding of death, judgment, resurrection, association with the ancestors and others.

Herein, we see some sort of problematic. First and foremost, from our exposition of the human person, we see that for the Tiv person, the human person is made up of four basic elements, of which Jijingi is regarded as the life force. This life force is also said to be eternal, just as the Uma. To be eternal however, it needs to combine with the Uma. By implication, the Jijingi and the Uma, cannot be eternal separately, they need to combine to be eternal. It herein seems to be that while the soul and the life force in the human body are separate, the life force provides lifeness to the $O r$, the human person. At death, the Jijingi still functions as the life giver to the soul, the Uma for it/their eternal existence. The question then is, would the Jijingi be considered as over and above the Uma? Is the Jijingi the mind? A second point worthy of note is that related to judgment. For the typical Tiv person, their burial is of great importance. A bad person is not buried with all the rites and after burial; his soul/spirit is summoned and punished, alongside his family. The question I wish to ask at this point is, what 'real' significance can cutting the person's soul/spirit is after his death? He cannot feel pain no hurt (at least that we belief), and at this point, all evil might have already been perpetuated.

In conclusion, even though some aspects of this typical culture might sound alien to few of us and perhaps unreasonable and unrealistic, the fact however remains that this understanding of the human person makes the Tiv man who he is.

\section{References}

1. Gbenda SJ (2003) Eschatology in Tiv traditional religious culture. An Interpretive Inquiry, p: 3.

2. Fromm F (1989) Max's conception of man. Frederick Ungar Publishing Company, New York, p: 24.

3. Metuh EE (1987) Comparative studies of African traditional religions. Imico Publishers, Onitsha, p: 175.

4. Tarbo NN (1980) Marriage among the Tiv. Pontifical Urban University, Rome, p: 20.

5. Sherrington C (1955) Man on his nature. Double Day, New York, p: 100.

6. Ekwunife ANO (1996) What is in a name, the philosophy of naming in igbo culture. Brigard Theological Studies 16: 36.

7. Kirk-Greene HM (1994) Mutumin Kirki, the concept of the goodman in hausa. Indiana University Bloomington, Indiana, p: 32.

8. Werblowsky RJZ (1987) Eschatology an overview. In: Eliade M (ed.), The encyclopedia of religion. Macmillan, New York 5: 149.

9. Omoregbe J (1993) Philosophical look at religion (Philosophy of Religion). JOJA Educational Research and Publishers p: 308. 